\title{
Macroinvertebrate interactions stimulate decomposition in WWTP effluent-impacted aquatic ecosystems
}

\author{
Tom V. van der Meer ${ }^{1}\left(\mathbb{D} \cdot\right.$ Gea H. van der Lee ${ }^{1} \cdot$ Ralf C. M. Verdonschot ${ }^{1} \cdot$ Piet F. M. Verdonschot ${ }^{1,2}$
}

Received: 26 January 2021 / Accepted: 23 July 2021 / Published online: 9 August 2021

(c) The Author(s) 2021

\begin{abstract}
Aquatic ecosystems worldwide are impacted by an influx of nutrients and sludge particles from wastewater treatment plant (WWTP) effluents, leading to a degradation of benthic habitats and a loss of associated macroinvertebrate taxa. Hence, in habitats impacted by WWTPs, only a few tolerant macroinvertebrate taxa remain. These tolerant detritivore macroinvertebrate taxa play an important role in the degradation of organic matter, and biotic interactions between these taxa may either enhance or reduce the rate of sludge degradation. Therefore, the aim of the present study was to examine if the interaction between asellids and tubificids, both highly abundant in systems impacted by WWTP effluent, enhances the degradation of sludge. To this end, growth and reproduction of both taxa, sludge degradation and nutrient concentrations in the overlying water were measured in a 28-day laboratory experiment, subjecting WWTP sludge to 4 treatments: a control without macroinvertebrates, a tubificid, an asellid, and an asellid + tubificid treatment. Sludge degradation, phosphate concentration in the overlying water and asellid reproduction were enhanced when asellids and tubificids were jointly present, whereas tubificid growth and reproduction were hampered in comparison to the tubificid treatment. Hence, our results suggest that the biotic interactions between these tolerant detritivores stimulate sludge degradation, and thus possibly mitigating the negative impacts of WWTP-derived sludge particles on the benthic environment.
\end{abstract}

Keywords Biotic interactions · Asellus aquaticus · Tubificinae $\cdot$ Wastewater treatment plant · OM degradation · Ecosystem function

\section{Introduction}

Water bodies worldwide are increasingly affected by effluents from wastewater treatment plants (WWTPs) (Hamdhani et al. 2020). WWTP effluents enrich the receiving water bodies with fine organic sludge particulates and nutrients (Ruggiero et al. 2006), which severely impacts aquatic and benthic habitats. As a result of increased microbial respiration and oxygen demand (Arce et al. 2014), dissolved oxygen concentrations decline, and moreover, the sludge particles accumulating in the benthic environment cover the sediment

Tom V. van der Meer

tom1.vandermeer@wur.nl

1 Wageningen Environmental Research, Wageningen University and Research, Droevendaalsesteeg 3, 6700AA Wageningen, The Netherlands

2 Institute for Biodiversity and Ecosystem Dynamics, University of Amsterdam, Science Park 904, 1090GE Amsterdam, The Netherlands substrate and clog the hyporheos (Sánchez-Morales et al. 2018). These impacts obviously affect the macroinvertebrate community composition (dos Reis Oliveira et al. 2020; Gieswein et al. 2019), and taxa sensitive to fine sediment particles and low oxygen concentrations disappear (Mor et al. 2019; Sánchez-Morales et al. 2018). The remaining invertebrate communities in WWTP effluent-enriched waters are frequently dominated by tolerant tubificids (Oligochaeta: Tubificinae) and asellids (Isopoda: Asellidae) that feed on organic matter (OM) (Burdon et al. 2019; Englert et al. 2013; Rueda et al. 2002).

By feeding on OM, detritivore macroinvertebrates, like asellids and tubificids, are key mediators in the degradation of detrital OM in aquatic ecosystems (Chauvet et al. 1993; Cook and Hoellein 2016; Graça 2001; Mermillod-Blondin et al. 2000). As multiple species of detritivores often have to share a common detrital food source and space in the benthic habitat, biotic interactions between these species may affect each other's performance, and therewith the rate of OM decomposition. Negative interactions, such as competition, 
can reduce the performance of a competitively inferior species (Costantini and Rossi 1998). This can either lead to increased or decreased OM decomposition, depending on whether the dominant competitor is a more efficient degrader (Creed et al. 2009) or not (Little and Altermatt 2018, see also Holomuzki et al. 2010). Competition can also lead to a shift in the trophic niche of one of the competitors, when the inferior competitor is forced to feed on another (part of the) food source. This complementary feeding can result in the consumption of a wider range of $\mathrm{OM}$ and thus an increased degradation of OM (Tonin et al. 2018, Sericostoma pyrenaicum vs. Echinogammarus berilloni). Negative interactions were also observed for sediment bioturbation, which was lower in an experimental treatment containing both asellids and tubificids than predicted from both single-species bioturbation activities (Mermillod-Blondin et al. 2004). These biotic interactions between asellids and tubificids did not result in a lower survival of either species, indicating only a weak negative interaction between the two taxa. Oppositely, also positive interactions can occur, e.g., when organisms exchange resources such as nutrients, or offer protection or habitat, which benefits at least one of the participants (Silknetter et al. 2020). For instance, trophic facilitative interactions occur when the feeding activity of one detritivore modifies the quality of the original food source for a consecutive species, which enhances the performance of the latter (Heard 1994). Tubificids can benifit from facilitive interaction with other tubificid species, as their growth is promoted when feeding on each other's feaces when compared to feeding on feaces of conspecifics (Milbrink 1993). Trophic facilitation has also been observed in multiple macroinvertebrate detritivore shedder interactions (Basen et al. 2013; Jonsson and Malmqvist 2005; Westveer et al. 2018; see also Hay et al. 2004). Due to this trophic facilitation, the detrital material is consumed more efficiently, which may positively affect the degradation rate of OM (Tonin et al. 2018, Leuctra geniculata or Lepidostoma hirtum combined with Sericostoma pyrenaicum). As such, biotic interactions between detritivores may strongly influence the rate of degradation of $\mathrm{OM}$ in aquatic systems.

The question remains however, how these biotic interactions and their effects on OM degradation are affected by the influx of WWTP-derived sludge particles and nutrients, since these interactions are not static, but rather depend on the ecological context (Holomuzki et al. 2010; Silknetter et al. 2020). The oxygen and nutrient concentrations in the water, and the physical composition of the substrate can affect the biotic interactions between detritivores in $\mathrm{OM}$ degradation (Fugère et al. 2012 and references therein). As macroinvertebrates play an important role in the processing of WWTP originated OM (Bundschuh and McKie 2016), assessing the effect of biotic interactions between the taxa remaining in these polluted and deteriorated aquatic ecosystems on sludge derived OM decomposition is key to understanding how these effluent-enriched systems function. However, research into biotic interactions between detritivores in effluent-enriched systems is currently lacking.

Therefore, the aim of the present study was to assess the effect of biotic interactions between asellids and tubificids on the degradation rate of sludge particles in WWTP effluent-affected benthic environments. We hypothesized that due to facilitative interactions, the performance of one or both taxa would be positively impacted, which would enhance the sludge degradation rate. To test this hypothesis, the effects of asellids and tubificids on sludge degradation were assessed in a 28-day laboratory experiment, with treatments consisting of either asellids, tubificids, or asellids + tubificids and a control without macroinvertebrates. WWTP sludge was used as OM source, as this represents the fine organic effluentassociated sludge particles that affect the aquatic ecosystems, and this setup thus represents a "worst-case scenario" in which the majority of available OM is effluent-associated. Organism growth and reproduction were selected as parameters for organism fitness. Sludge degradation, chemical oxygen demand, and nutrient concentrations in the overlying water were measured at the start and the end of the experiment to determine the effect of biotic interactions on the sludge degradation.

\section{Materials and methods}

\section{Experiment}

\section{Collection of sludge}

Sludge from the aeration tank of the WWTP Bennekom (22,000 population equivalents, Bennekom, The Netherlands, $51^{\circ} 59^{\prime} 49.01^{\prime \prime} \mathrm{N}$ : $5^{\circ} 39^{\prime} 28.36^{\prime \prime} \mathrm{E}$ ) was used as a source of $\mathrm{OM}$ in all experiments. The sludge $\left[2.8 \pm 0.1 \mathrm{~g} \mathrm{~L}^{-1}\right.$ total suspended solids (mean $\pm \mathrm{SD}$ )] was collected in $10 \mathrm{~L}$ buckets and stored at $4{ }^{\circ} \mathrm{C}$ under aeration.

\section{Collection and acclimatisation of specimens}

Tubificids were bought from a fish food wholesale (Aquadip, the Netherlands) and comprised multiple taxa, consisting of Limnodrilus hoffmeisteri, L. claparedeianus and Tubifex sp. Asellids (Asellus aquaticus) were collected from ditches at the Wageningen University campus (Wageningen, The Netherlands, 51 ${ }^{\circ} 59^{\prime} 14.56^{\prime \prime} \mathrm{N}: 5^{\circ} 39^{\prime} 36.49^{\prime \prime} \mathrm{E}$ ).

Tubificids and asellids were kept separately in $50 \mathrm{~L}$ tanks $(118 \cdot 29 \bullet 18 \mathrm{~cm})$ in aerated Dutch Standard Water (DSW, deionized water with an addition of $200 \mathrm{mg} \mathrm{L}^{-1}$ $\mathrm{CaCl}_{2} \cdot 2 \mathrm{H}_{2} \mathrm{O}, 180 \mathrm{mg} \mathrm{L}^{-1} \mathrm{MgSO}_{4} \cdot 7 \mathrm{H}_{2} \mathrm{O}, 100 \mathrm{mg} \mathrm{L}^{-1}$ $\mathrm{NaHCO}_{3}$, and $20 \mathrm{mg} \mathrm{L}^{-1} \mathrm{KHCO}_{3}$ ) at a constant water 
temperature of $19.2 \pm 1.0{ }^{\circ} \mathrm{C}$ with a $16: 8 \mathrm{~h}$ light: dark cycle during three weeks before the start of the experiment. Both taxa were fed ground fish food (Tetramin, Tetra ${ }^{\mathrm{TM}}$ Germany) every other day ad libitum. Additionally, the asellids were provided with a layer of sand and senescent Alnus glutinosa leaves on the bottom of the tank. Water renewal of fifty percent of the DSW was performed weekly.

To allow for acclimation to the experimental conditions, the animals were transferred separately to the same type of $50 \mathrm{~L}$ aerated tanks, with a DSW to sludge ratio of $3.5: 1$, resulting in a $1.5 \mathrm{~cm}$ layer of settled solids, for 7 days prior to the experiment. All animals were starved for $24 \mathrm{~h}$ before the start of the 28-day experiment to ensure depuration of the gut content.

\section{Experimental set-up}

The sludge was exposed to asellids (A), tubificids (T), or asellids + tubificids $(A+T)$, resulting in three treatments, plus a control without macroinvertebrates (C) (Fig. 1). As it was logistically unfeasible to perform all treatments simultaneously, the $\mathrm{A}+\mathrm{T}$ and T-treatments (Run 1) were initiated on 09-05-2019, while the A-treatment was started on 24-102019 (Run2). Controls were included in both parts of the experiment ( $\mathrm{C} 1$ and $\mathrm{C} 2$, respectively).

Five replicate experimental tanks per treatment $(25 \bullet 15 \bullet 15 \mathrm{~cm}, 5 \mathrm{~L}$, polyethylene) were provided with
$350 \mathrm{~mL}$ sludge, corresponding to about $1000 \mathrm{mg}$ of total solids and filled to $4.45 \mathrm{~L}$ with DSW. To determine the initial physicochemical conditions of the tanks, 10 (Run 1) and 5 (Run 2) additional tanks were prepared and used to directly collect samples nutrients, Chemical Oxygen Demand (COD) and total solids (indicated as S1 and S2, respectively). Separate tanks were used to determine initial conditions, instead of the control tanks, due to the destructive nature of the solid sampling. Following the settling of the solids after $\pm 30 \mathrm{~min}$, the aeration system was turned on.

Each replicate, except for the control, received either 26 asellid individuals $(7.9 \pm 1.5 \mathrm{~mm}$; male:female ratio $0.94 \pm 0.07$ ) in the A-treatment, a wet weight of $500 \mathrm{mg}$ of tubificids in the T-treatment, or 13 asellid individuals $(8.3 \pm 1.5 \mathrm{~mm}$; male:female ratio $0.88 \pm 0.44)$ and a wet weight of $250 \mathrm{mg}$ of tubificids in the A+T-treatment, corresponding to a total of $80 \pm 5,80 \pm 0$ and $86 \pm 3 \mathrm{mg}$ of dry animal biomass per replicate, respectively.

After addition of the animals, the tanks were covered with transparent plastic lids. Light and temperature conditions remained constant during the experiment. Dissolved oxygen concentration, water temperature and $\mathrm{pH}$ were measured in all tanks twice a week with a multimeter (HQ40D, $\mathrm{Hach}^{\mathrm{TM}}$ Germany), and demineralized water was added to compensate for evaporation losses.

At the end of the 28-day experiment, a $20 \mathrm{~mL}$ water sample was taken for nutrient analyses from each replicate. All

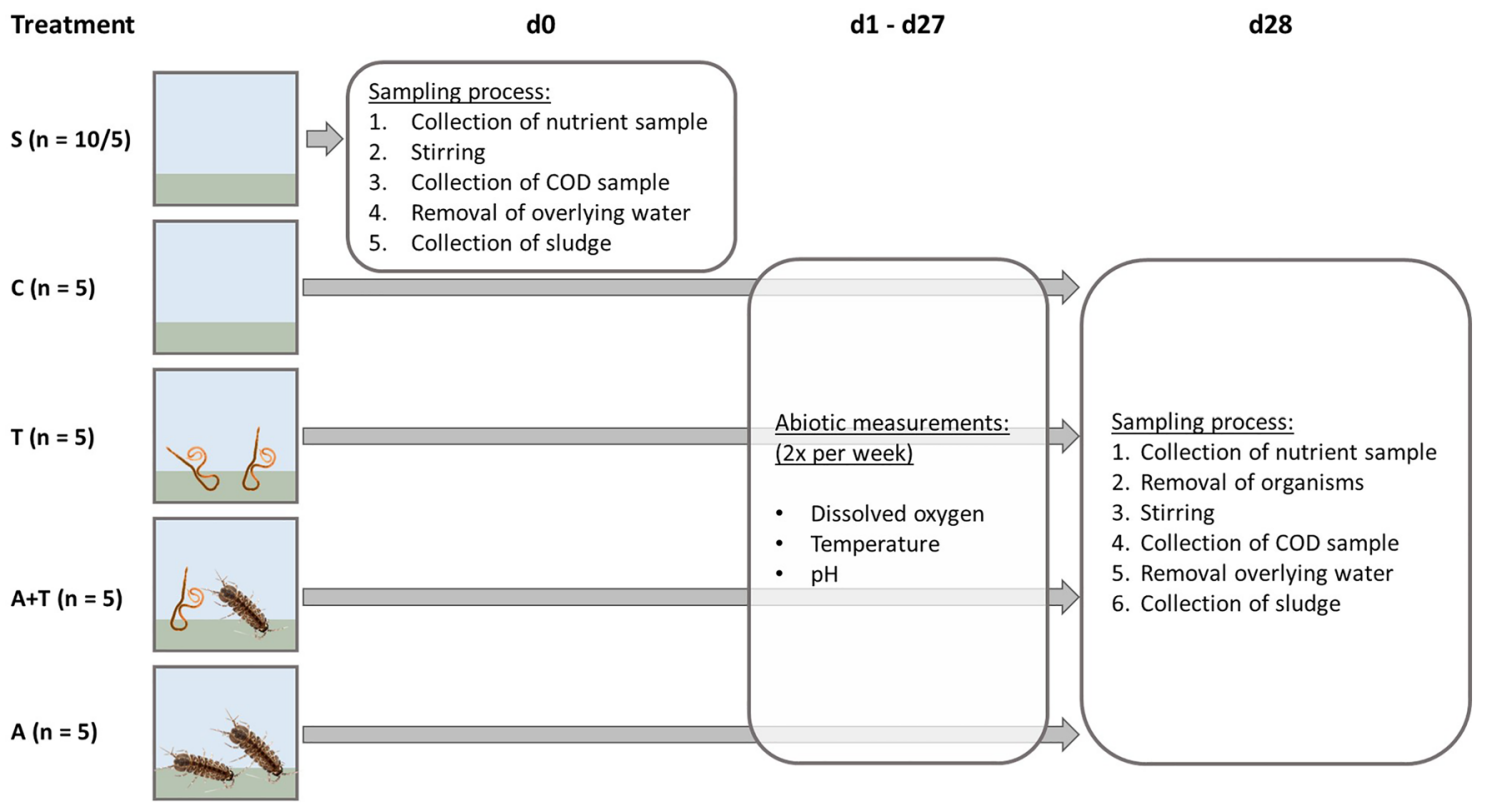

Fig. 1 Diagram of experimental setup: sludge degradation by macroinvertebrates was assessed in a 28 day experiment with a tubificid treatment (T: $n=5)$, an asellid treatment (A: $n=5)$ and an asellid+tubificid treatment $(\mathrm{A}+\mathrm{T}: n=5)$. A control $(\mathrm{C}: n=5)$ was included to determine macroinvertebrate degradation relative to the inherent degradation of the sludge. To determine initial physiochemical conditions of the experimental tanks, separate tanks were sacrificed and directly sampled on day $0(\mathrm{~S}: n=10 / 5)$. The experiment was performed in two runs, and the results of these runs were combined. Water quality parameters were measured twice a week 
animals present in the tanks were collected in small containers with DSW, and adhering sludge was transferred back to the experimental tanks. Juvenile asellids and tubificid cocoons were collected separately. After removal of the animals, solids were re-suspended in the water column, and a $10 \mathrm{~mL}$ sample was taken for COD analysis, after which the sludge present in the tanks was collected. Samples were stored overnight before further processing (see Data collection).

\section{Data collection}

\section{Macroinvertebrate biomass and reproduction}

Asellids Dry weight of the asellids at the start and at the end of the experiment was calculated with a length-dry weight conversion formula obtained by (Graça et al. 1993). The asellids were photographed dorsally in groups of 13 individuals, and their length was measured from the top of the head, following the middle of the back, to the tip of the telson, using FIJI software (ImageJ 1.52p). The length of 15 females in pre-copula position could not be determined at the start of the experiment. Therefore, 24 completely visible females were randomly selected from the photographs, from which the ratio between the length and the maximum width of the last segment was determined. This ratio was used to estimate the length of 12 of the 15 pre-copula females. The three remaining pre-copula position females were not visible at all, and therefore their length was set to that of the smallest completely visible female in the dataset $(4.4 \mathrm{~mm})$, as the smallest females were least visible. Reproduction was used as a parameter for asellid fitness rather than survival, as asellids are often regarded as a semelparous species (Arakelova 2001; Chambers 1977; Murphy and Learner 1982), and thus a high adult mortality after reproduction could be expected. Asellid reproduction was expressed as the ratio between the number of juveniles at the end of the experiment and the number of initially added adult asellids.

Tubificids Tubificid wet weight at the start of the experiment was determined after removal of the surface moisture with a paper towel. To prevent gut content affecting final tubificid wet and dry weights, the animals were starved for $24 \mathrm{~h}$ before the determination of both the starting and end wet weight. After determining their wet weight at the end of the experiment, the tubificids were dried at $90{ }^{\circ} \mathrm{C}$ for $24 \mathrm{~h}$ and weighed again to determine dry weight. The dry:wet weight ratio of the tubificids at the end of the experiment was used to calculate the initial dry weight of the tubificids at the start of the experiment. Because the growth rate of adult tubificids might be limited, as most of their energy is allocated into reproduction (Finogenova and Lovasheva 1987), reproduction was also taken into account as an indi- cator of their performance. Tubificid reproduction was expressed as the number of cocoons per dry weight of the initial tubificid biomass.

Total solids and chemical analyses For the determination of the physicochemical conditions in the tanks, a $20 \mathrm{~mL}$ sample for nutrient analyses was collected using a syringe with a $0.45 \mu \mathrm{m}$ cellulose acetate filter. For the COD analysis, first the solids in the tank were re-suspended, and a $10 \mathrm{~mL}$ sample was collected. To determine the concentration of total solids, solids were allowed to settle in the tank, the overlaying water was removed, and the solids were poured into a $1 \mathrm{~L}$ polyethylene (PE) bottle. All samples were stored overnight at $4{ }^{\circ} \mathrm{C}$ before analysis.

Nutrient and COD samples were allowed to attain room temperature before they were analysed with a LCK cuvette kit for $\mathrm{PO}_{4}$ (LCK349), $\mathrm{NO}_{3}$ (LCK339) and COD (LCK514), and a spectrophotometer (DR3900, Hach $^{\mathrm{TM}}$ Germany) according to the manufacturer protocols. Samples were diluted with DSW if initial values exceeded the measuring range of the cuvette kits. To determine the total solids, the overlaying water in the PE bottles was removed, the settled solids were poured into a crucible, dried at $90{ }^{\circ} \mathrm{C}$ for $72 \mathrm{~h}$, and subsequently weighed.

\section{Data analysis}

Due to the small sample sizes, only non-parametric tests were performed on the data. For differences in asellid and tubificid reproduction, and relative tubificid biomass increase between treatments, non-parametric Kruskal-Wallis (KW) tests were performed. A Wilcoxon Signed Rank (WSR) test was applied to test for differences in tubificid biomass between the start and end of the experiment.

The effect of the different treatments on total solids, COD, $\mathrm{PO}_{4}$ and $\mathrm{NO}_{3}$ concentration, was expressed as the difference between each replicate of $\mathrm{A}, \mathrm{T}$ or $\mathrm{A}+\mathrm{T}$ and the average of the control of their respective run. This approach was taken as two runs were performed, and the initial physiochemical parameters of the sludge may differ between runs, which can affect the intrinsic sludge degradation. This approach thus might limit the effects of differences in initial parameters and emphasizes the effect of the macroinvertebrates on the degradation of the sludge relative to the intrinsic degradation of the sludge. Initial and final values of all variables can be found in Table S1. To determine if treatment $(\mathrm{A}, \mathrm{T}$, or $\mathrm{A}+\mathrm{T})$ had an effect, a KW test was performed on each variable, followed by a Dunn's post hoc test with a Benjamini-Hochberg correction for multiple comparisons.

To determine if biotic interactions had an effect on these variables, a predicted effect was calculated 5 times by averaging a random sample from the A-treatment and the T-treatment, excluding previously picked samples (Fugère et al. 
2012). This resulted in 5 replicates of an A+T-predicted treatment. To compare the predicted $\mathrm{A}+\mathrm{T}$ treatment with the observed $\mathrm{A}+\mathrm{T}$ treatment, a KW test was used. All analyses were performed in core R 3.6.1 (R Core team 2020), with the dunn.test package (Dinno 2017) to perform the Dunn's tests. A $p$ value of 0.05 or lower was considered as significant. Figures were produced using the ggplot2 (Wickham 2016) and ggpubr (Kassambara 2020) packages.

\section{Results}

\section{Experimental conditions}

Experimental conditions remained stable during the 28-day experiment, with a dissolved oxygen concentration of $8.91 \pm 0.35 \mathrm{mg} \mathrm{L}^{-1}$ and a $\mathrm{pH}$ of $8.07 \pm 0.23$ in the overlying water. In one tank of the T-treatment a short-term $(<24 \mathrm{~h})$ outlier in dissolved oxygen concentration $\left(2.5 \mathrm{mg} \mathrm{L}^{-1}\right)$ was observed due to a mechanical malfunction in the aeration system at the 12th day of the experiment (For experimental conditions over time, see Supplementary materials, Figure S1).

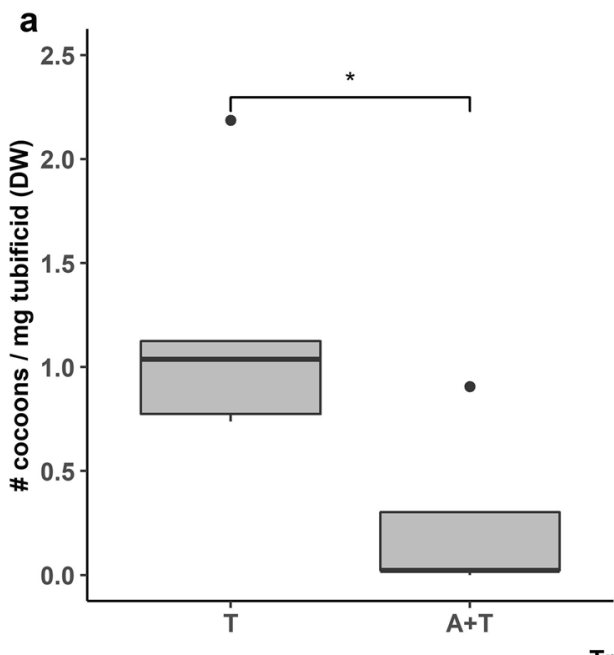

Fig. 2 Boxplots of macroinvertebrate reproduction in the $\mathrm{A}, \mathrm{T}$ and A + T-treatments ( $A$ asellid treatment, $A+T$ asellid + tubificid treatment, $T$ tubificid treatment), significant (Kruskal-Wallis, $p<0.05$ ) differences are indicated by an asterisk. a Tubificid reproduction as the number of cocoons/mg DW tubificids) was $=$ lower in the $\mathrm{A}+\mathrm{T}$ treatment when compared to the T-treatment. b Asellid reproduction
Tubificid and asellid reproduction and biomass

\section{Reproduction}

The tubificids had a reduced performance in the A+T-treatment compared to the T-treatment, as the median tubificid reproduction was 0.02 cocoons/tubificid $\mathrm{mg} \mathrm{DW}$, while the median reproduction in the T-treatment was 1.04 cocoons/tubificid mg DW $\left(\mathrm{KW}-\chi^{2}=4.8, \mathrm{df}=1, p=0.028\right)$ (Fig. 2a). In contrast, the median asellid reproduction was approximately 5.5 times higher in the $\mathrm{A}+\mathrm{T}$-treatment (median $=11.4$ juveniles/initial adult) than in the A-treatment $($ median $=2.1$ juveniles/initial adult $)\left(\mathrm{KW}-\chi^{2}=5.6\right.$, $\mathrm{df}=1, p=0.016)($ Fig. 2b).

\section{Biomass}

The tubificid biomass in the T-treatment was significantly higher after 28 days than at the start of the experiment (WRS- $W=2.5, p=0.025$ ), whereas the tubificid biomass in the A+T-treatment did show a decreasing trend, although not significant (WRS-W $=20, p=0.12$ ). Nonetheless, the relative increase in tubificid biomass did not differ significantly between the T-treatment (median $=0.212)$ and $\mathrm{A}+\mathrm{T}$-treatment $($ median $=-0.093)\left(\mathrm{KW}-\chi^{2}=2.5, \mathrm{df}=1\right.$, $p=0.12$ ) (Fig. 3). This was most likely caused by an outlier in the A+T-treatment that had a large effect on the obtained results, as the biomass of the A+T-treatment tubificids was significantly lower at the end of the experiment

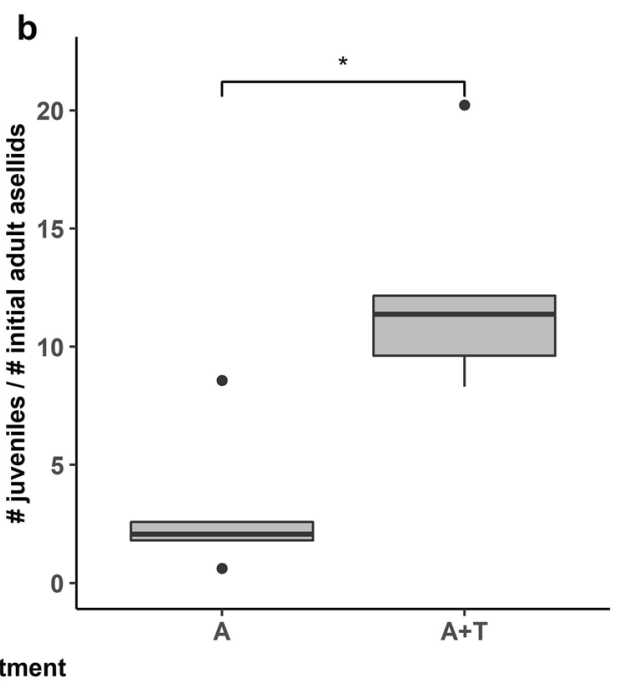

(as the number of juveniles/number of initial adults) was higher in the $\mathrm{A}+\mathrm{T}$ than in the A-treatment. Boxes show interquartile range, bold lines represent the median, whiskers indicate the lowest and highest values within a $1.5 \times$ interquartile range from the box, dots represent outliers 


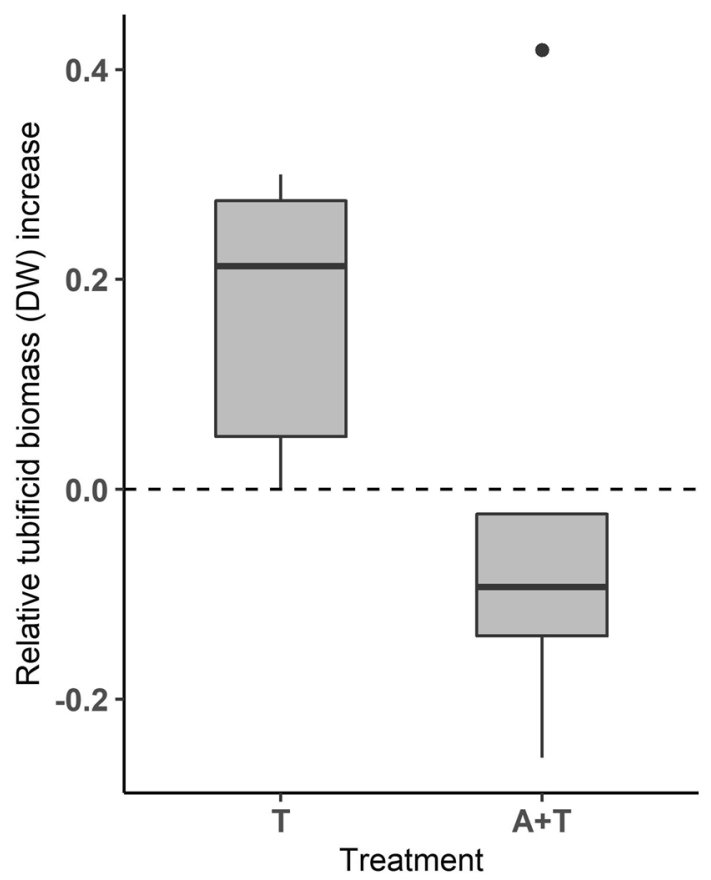

Fig. 3 Boxplots of the relative tubificid biomass (DW) increase in the tubificid $(\mathrm{T})$ and asellid + tubificid $(\mathrm{A}+\mathrm{T})$ treatment [(end DW-start DW)/start DW]. Relative tubificid biomass did not differ between treatments $(p=0.12)$, but exclusion of 1 outlier in the $\mathrm{A}+\mathrm{T}$ treatment did result in a higher relative biomass in the T-treatment $(p=0.014)$ $(\mathrm{KW})$. Boxes show interquartile range, bold lines represent the median, whiskers indicate the lowest and highest values within $1.5 \times$ interquartile range from the box, dots represent outliers

(WRS-W $=16, p=0.021$ ), and a significant difference in relative biomass increase between the T-treatment and $\mathrm{A}+\mathrm{T}$-treatment was observed $\left(\mathrm{KW}-\chi^{2}=6, \mathrm{df}=1, p=0.014\right)$ when this outlier was excluded. As asellid mortality was high in both the A-treatment (19 individuals \pm 2.8 corresponding to $82 \% \pm 16)$ and the A + T-treatment (11 individuals \pm 2.1 corresponding to $73 \% \pm 11$ ), asellid biomass increase was not calculated.

It must be noted that the control also harboured an average tubificid biomass of $17.8 \pm 16.5 \mathrm{mg}$ DW at the end of the experiment. This corresponds to, respectively, 22.5 and $44.5 \%$ of the initial tubificid dry weight in the $\mathrm{T}$ and A + T-treatments. Except for a single cocoon in one tank, no cocoons were found in the control at the end of the experiment. This indicated that the initial WWTP sludge contained recently hatched tubificids, which were too small to be noted at the start of the experiment.

\section{Total solids and abiotic variables}

Microbial activity was responsible for a decrease in total solids from roughly $1000 \mathrm{mg}$ DW at the start of the experiment to $600 \mathrm{mg}$ DW in the controls (supplementary materials,
Table S1). Macroinvertebrate treatment significantly affected the amount of total solids remaining relative to the control $\left(\mathrm{KW}-\chi^{2}=11.1\right.$, df $(2 p<0.005)$ (Fig. 4a). Remaining solids relative to the control were significantly lower in the $\mathrm{A}+\mathrm{T}$-treatment $($ median $=-97.7 \mathrm{mg})$ than in the T-treatment $($ median $=28.3 \mathrm{mg})(p<0.005)$, and appeared to be lower, although non-significant, compared to the A-treatment $(p=0.12)$. The combination treatment resulted in a higher reduction of total solids than predicted from the single taxa treatments $\left(\mathrm{KW}-\chi^{2}=6.8, \mathrm{df}=1, p<0.01\right)$, indicating that biotic interactions played a significant positive role in the decomposition of sludge.

Chemical Oxygen Demand concentrations appeared to be only marginally affected by treatment relative to the control $\left(\mathrm{KW}-\chi^{2}=4.9, \mathrm{df}=2, p=0.09\right)$, as the relative COD concentration in the $\mathrm{A}+\mathrm{T}$-treatment appears to be marginally lower than in the A-treatment $(p=0.10)$. The $\mathrm{A}+\mathrm{T}$-treatment did reduce $\mathrm{COD}$ concentrations more than was expected from the single-species treatments $\left(\mathrm{KW}-\chi^{2}=6.8, \mathrm{df}=1, p<0.01\right)$, indicating biotic interactions could have affected the reduction in COD (Fig. 4b).

The degradation of OM resulted in an increase in both $\mathrm{PO}_{4}-\mathrm{P}$ and $\mathrm{NO}_{3}-\mathrm{N}$ in the overlying water in all treatments, including the control, relative to the nutrient concentrations at the start of the experiment (supplementary materials, Table S1). Treatment did affect the $\mathrm{PO}_{4}-\mathrm{P}$ concentration relative to the control at the end of the experiment (KW$\left.\chi^{2}=9.8, \mathrm{df}=2, p<0.01\right) . \mathrm{PO}_{4}-\mathrm{P}$ concentrations relative to the control were lower in the T-treatment than the other treatments $(p<0.05)$ (Fig. $4 \mathrm{c})$. Although the $\mathrm{PO}_{4}-\mathrm{P}$ concentration in the $\mathrm{A}+\mathrm{T}$-treatment did not differ from the A-treatment $(p=0.5)$, it was significantly higher than the concentration predicted from both single taxa treatments $\left(\mathrm{KW}-\chi^{2}=4.8, \mathrm{df}=1, p<0.05\right)$.

Relative $\mathrm{NO}_{3}-\mathrm{N}$ concentrations were also affected by treatment $\left(\mathrm{KW}-\chi^{2}=12.5, \mathrm{df}=2, p<0.005\right)$, as the concentration in the A-treatment was significantly higher compared to the T-treatment $(p<0.05)$, and marginally higher compared to the $\mathrm{A}+\mathrm{T}$ treatment $(p=0.08)$. Unlike the $\mathrm{PO}_{4}-\mathrm{P}$ concentration, the $\mathrm{NO}_{3}-\mathrm{N}$ concentration in the $\mathrm{A}+\mathrm{T}$-treatment did not differ from the concentrations predicted from the single taxa treatments $\left(\mathrm{KW}-\chi^{2}=0.01, \mathrm{df}=1, p=0.9\right)$. This indicates that the $\mathrm{PO}_{4}-\mathrm{P}$ release was affected by biotic interactions, while $\mathrm{NO}_{3}-\mathrm{N}$ release was not.

\section{Discussion}

\section{Macroinvertebrate biotic interactions}

In line with our hypothesis, the asellids were positively affected by the interspecific interactions, as their reproduction was enhanced by the presence of the tubificids. 

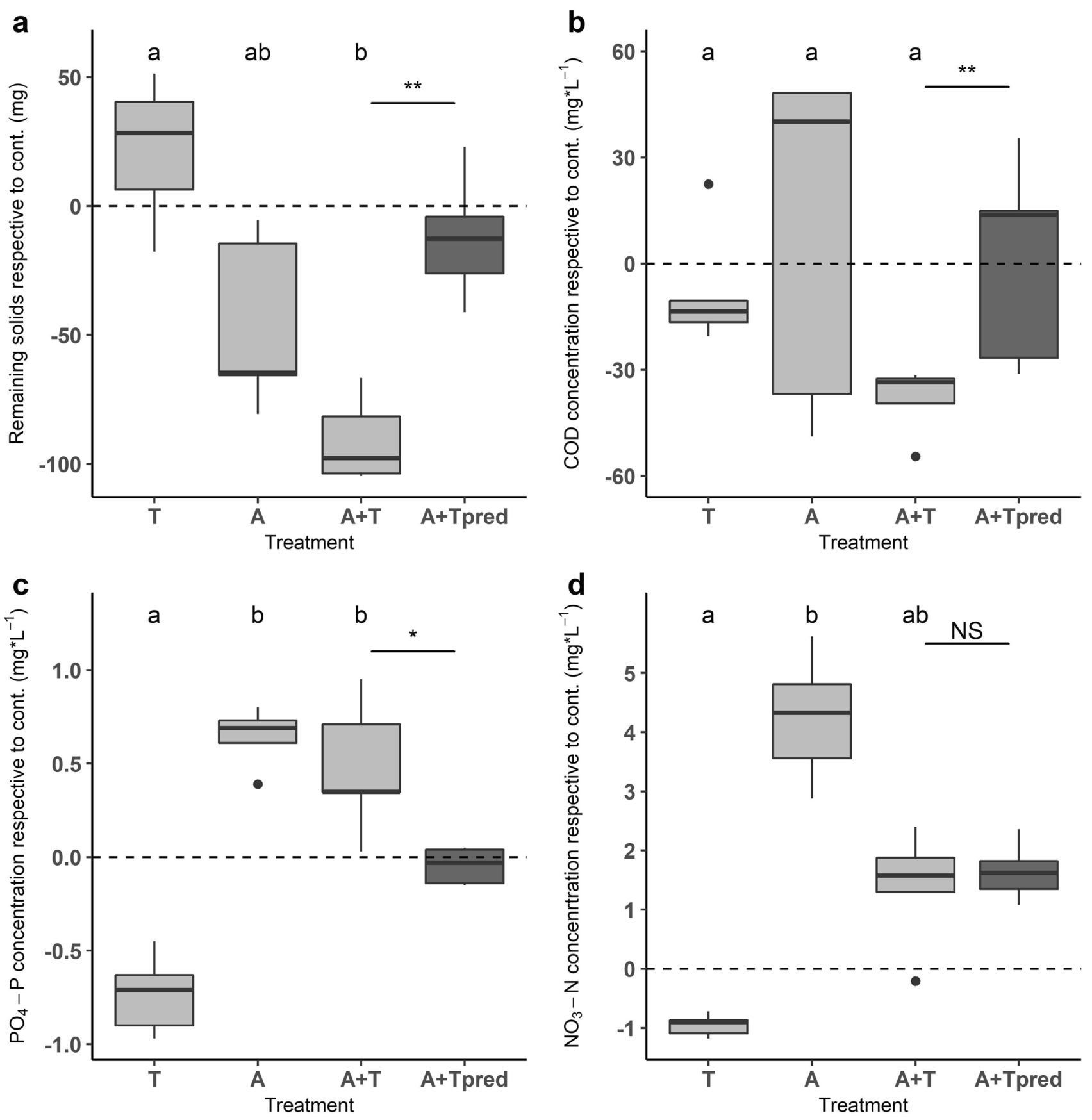

Fig. 4 Boxplots of the differences in abiotic environmental variables between the control and the tubificid $(\mathrm{T})$, asellid (A), asellid + tubificid $(\mathrm{A}+\mathrm{T})$ (all light grey) and predicted asellid + tubificid (A+Tpred; dark grey) treatments at the end of the 28 days experiment. a Total solids (mg DW), b Chemical oxygen demand $\left(\mathrm{mg} \mathrm{L}^{-1}\right)$, c Phosphate concentration in the overlying water $\left(\mathrm{PO}_{4}-\mathrm{P} \mathrm{mg} \mathrm{L}{ }^{-1}\right)$, and $\mathrm{d}$ : Nitrate concentration in overlying water $\left(\mathrm{NO}_{3}-\mathrm{N} \mathrm{mg} \mathrm{L}^{-1}\right)$.

Contrary, the tubificids were hampered by the interaction, with a reduced reproduction and growth in the presence of the asellids. Multiple negative interactions could have affected the tubificids in our experimental system, including

Boxes show interquartile range, bold lines represent the median, whiskers indicate the lowest and highest values within $1.5 \times$ interquartile range from the box, dots represent outliers. Letters indicate significant $(p<0.05$, Dunn's posthoc) differences between the T-, A- and A+T-treatments, while asterisks indicate significant differences between the $\mathrm{A}+\mathrm{T}$ - and predicted $\mathrm{A}+\mathrm{T}$-treatments $(* p<0.05, * * p<0.01)$

competition for space, which could have functioned as a competitive resource. Asellids are active bioturbators (Hunting et al. 2012), mixing the upper $3 \mathrm{~cm}$ of the sediment (Mermillod-Blondin et al. 2002), and the tubificids may 
have reacted to these thigmotactic and phototactic stimuli by a quick retraction movement (Drewes and Fourtner 1989; Zoran and Drewes 1987). Thus, frequent thigmotactic stimuli, or even the physical presence of the asellids may have led to a smaller amount of time spent on feeding by the tubificids, resulting in a decreased performance. Such interspecific disturbance responses have previously been observed in chironomid larvae and snail assemblages (Gresens 1995).

Competition for food could have been another negative interaction between the asellids and tubificids. The asellids might have been able to outcompete the tubificids in acquiring a larger portion or a more nutritious part of the sludge. The interspecific competition in the $\mathrm{A}+\mathrm{T}$-treatment might have been less stringent for the asellids than the intraspecific treatment in the A-treatment, thus leading to a higher performance of asellids in the A+T-treatment. Lower detritivore performance at higher population densities has been observed before, as niche overlap with conspecifics is presumed to be higher than with other species (McKie et al. 2008). Increasing species richness while keeping organism density equal could have lowered negative intraspecific interactions for the asellids (McKie et al. 2009), while still hampering the performance of the tubificids. Likewise, as the tubificids in our experiment consisted of multiple species which are known to affect each other positively in a facilitative interaction (Milbrink 1993), a lower density of tubificids would lower the possibility and strength of this facilitative interaction between individual tubificids and thus possibly would also lower their performance.

These density effects do not, however, explain the increased $\mathrm{OM}$ degradation in the $\mathrm{A}+\mathrm{T}$-treatment, relative to the two single taxa treatments. Trophic niche differentiation by the tubificids could result in an increase in OM degradation. As the asellids might have outcompeted the tubificids for the more nutritious or digestible part of the available sludge, this could have forced the tubificids to feed on the less nutritious parts of the sludge. Tubificid feeding on lower-quality sludge would reduce their performance, but, as by both species together a larger part of the sludge was digested, this would also result in a higher total degradation of sludge. Trophic niche differentiation has been described before in competitive interactions between A. aquaticus and the snail Potamopyrgus antipodarum, which led to a shift in the trophic niche of the latter (Aberle et al. 2005). Enhanced OM degradation through niche partitioning has also been observed in experiments with gammarids and caddisfly larvae (Tonin et al. 2018).

Moreover, asellids can possibly prey on tubificid cocoons as they feed on a wide range of food items including animal derived material (Marcus et al. 1978). Tubificids consist mainly of proteins (Ratsak and Verkuijlen 2006), and their eggs, despite protected by a cocoon, will likely be of similar protein content. Under natural conditions, tubificids will deposit their cocoons in deeper sediment layers in the presence of predators (Newrkla and Mutayoba 1987). This was not possible in the present experimental setup, as the sludge had a limited depth, and was easily moved aside through asellid bioturbation. As a deeper benthic habitat offers more possibilities for cocoon deposition by the tubificids, as well as the avoidance of asellid bioturbation behaviour, this might also explain the difference between the outcome of the asellid-tubificid interaction compared to Mermillod-Blondin et al. (2004), who did not find a negative effect on the survival of both taxa, as the height of the sediment layer in their mesocosms was $40 \mathrm{~cm}$. On the other hand, changes in sludge characteristics by asellid bioturbation could have indirectly caused cocoon losses by promoting conditions for bacterial attacks on cocoons (Wisniewski 1979).

\section{Enhanced OM degradation and effects on nutrient dynamics}

Regardless of the underlying biotic interactions, we did observe an enhanced sludge reduction, indicated by a lower amount of remaining total solids, in the $\mathrm{A}+\mathrm{T}$-treatment compared to the sludge reduction predicted from both single taxa treatments. These findings supported our hypothesis that degradation of sludge $\mathrm{OM}$ would be enhanced due to species interactions. The combination of two or more species enhancing the degradation of OM has been observed before, but only in setups with predominantly macroinvertebrate shredders and leaf disks (Jonsson and Malmqvist 2000; Ohta et al. 2016; Tonin et al. 2018). To our knowledge, this experiment is the first observation of enhanced decomposition using sludge OM derived from WWTP sludge and macroinvertebrate collector-gatherers. Our findings thus emphasize that biotic interactions enhancing decomposition are not limited to shredders in (semi)natural systems (Jonsson and Malmqvist 2000; Ohta et al. 2016; Tonin et al. 2018), but can also apply to collector-gatherers in humanimpacted systems.

The concentration of $\mathrm{PO}_{4}-\mathrm{P}$ in the overlying water showed the inverse pattern as the reduction of total solids, being higher in treatments with less remaining solids. This is likely due to the release of $\mathrm{PO}_{4}-\mathrm{P}$ from the sludge $\mathrm{OM}$, as the sludge is degraded (Hieber and Gessner 2002). The higher than expected $\mathrm{PO}_{4}-\mathrm{P}$ concentration in the $\mathrm{A}+\mathrm{T}$-treatment is thus likely a result of the higher than expected degradation of solids in the $\mathrm{A}+\mathrm{T}$ treatment. Although the degradation of solids seemed higher in the $\mathrm{A}+\mathrm{T}$ treatment than in the A treatment, this was not reflected in the $\mathrm{PO}_{4}-\mathrm{P}$ concentration, which did not differ. This might be due to the bioturbation activity of the asellids, which might promote the transfer of $\mathrm{PO}_{4}-\mathrm{P}$ from the sludge layer to the overlaying water (Gautreau et al. 2020), regardless of tubificid presence. Nitrate, on the other hand, was not impacted by biotic 
interactions, as the predicted and observed $\mathrm{NO}_{3}-\mathrm{N}$ concentrations were similar. However, the nitrogen released during the breakdown of sludge can also be present in multiple other forms that were not measured in this study, such as nitrite and ammonia, which might explain why $\mathrm{NO}_{3}-\mathrm{N}$ had a different pattern than $\mathrm{PO}_{4}-\mathrm{P}$.

\section{Management and WWTP implications}

Our results suggest that biotic interactions can enhance the reduction of WWTP-derived sludge OM, although we were not able to disentangle all biotic interactions occurring in our experiment. The effects of macroinvertebrate interactions on the degradation of sludge have been demonstrated here on a small scale, and with a relatively small sample size. Further research on a larger spatial-temporal scale with a wider array of species is needed to best grasp the implications of these complex biotic interactions. Specifically, if these findings are reproduced in a larger setup, they could potentially have large implications for WWTP effluent-affected aquatic systems. If macroinvertebrate interactions enhance the breakdown of effluent-associated $\mathrm{OM}$ in affected systems, the presence of multiple tolerant detritivore macroinvertebrates might mitigate some of the negative impacts of WWTP effluents, by preventing accumulation of sludge particles and clogging of the benthic habitat. Thus, these interactions might play an important role in the selfpurifying capacity of aquatic systems (González et al. 2014).

This subsequently also has implications on the effects of the loss of detritivore species from aquatic systems. As the rate of OM degradation in an aquatic system by a detritivore community might be larger than the sum of its individual species, the loss of a detritivore species might also result in a more severe reduction in OM degradation than would be expected from single-species assessments (Tonin et al. 2018). Moreover, the loss of a detritivore species might trigger a cascade of species disappearances, as with the loss of each detritivore species not only is the capacity to breakdown the sludge OM reduced, but also the capability to mitigate the WWTP effluent impacts, and the facilitative interactions this species had with other species (e.g. Stress Gradient Hypothesis and Biological Marketplace, see Silknetter et al. 2020). On the other hand, if benthic habitat conditions are improved, for example, due to a reduction in WWTP discharges, and detritivore species return, their biotic interactions might enhance sludge breakdown, and thus accelerate a further recovery of the affected system (Halpern et al. 2007). When managing WWTP effluent-impacted surface waters, it is therefore important to take possible interactive effects between macroinvertebrate species into account that may positively impact ecosystem functioning.

The understanding of facilitative interactions and selfpurifying processes of aquatic systems is not only important for management and predictive purposes, but might also allow us to harness the potential of macroinvertebrates and their interactions to act as an additional treatment step at WWTPs. This might allow sludge OM and nutrients in the effluent to be more efficiently removed using combinations of species in a controlled environment (Schuijt et al. 2021).

\section{Conclusion}

This study showed that the interactions between macroinvertebrates can enhance the degradation of effluent-associated organic matter. These interactions might therefore mitigate some negative impacts of effluent discharges and could play a role in the self-purifying processes of aquatic systems. When managing WWTP effluent-impacted surface waters, it is therefore important to take possible interactive effects between macroinvertebrate species into account that may positively impact ecosystem functioning. This small-scale study emphasizes that we should not consider macroinvertebrates species as solitary actors, but rather as part of a community when assessing their effect on ecosystem processes, and that these processes, such as OM degradation, are impacted by their interactions.

Supplementary Information The online version contains supplementary material available at https://doi.org/10.1007/s00027-021-00821-8.

Acknowledgements We would like to thank Lissy Denkers, Bo Schouten, Laura Misker and Siena Schickler for their help with the collection of macroinvertebrates and the experiment, Katja Grolle and staff of RWZI Bennekom for permission to collect sludge at the WWTP, and Michiel Kraak for advice on the structure of the manuscript.

Author's contributions T. van der Meer, P. Verdonschot and R. Verdonschot contributed to the conception and design of the study. Material preparation, data collection and analysis were performed by $\mathrm{T}$. van der Meer and G. van der Lee. The first draft of the manuscript was written by $\mathrm{T}$. van der Meer and all authors commented on previous versions of the manuscript. All authors read and approved the final manuscript.

Funding This work is funded by three Dutch waterboards; Hoogheemraadschap De Stichtse Rijnlanden, Hoogheemraadschap Hollands Noorderkwartier, and Waterschap Rivierenland.

Data availability Upon reasonable request, the data that supported our results and conclusions are available from the corresponding author.

Code availability Upon reasonable request, the code used to analyse the data that supported our results and conclusions is available from the corresponding author.

\section{Declarations}

Conflict of interest The authors have no relevant financial or non-financial interests to disclose. 
Ethical approval No approval of research ethics committees was required to accomplish the goals of this study because experimental work was conducted with unregulated invertebrate species.

Consent to participate Not applicable.

Consent for publication Not applicable.

Open Access This article is licensed under a Creative Commons Attribution 4.0 International License, which permits use, sharing, adaptation, distribution and reproduction in any medium or format, as long as you give appropriate credit to the original author(s) and the source, provide a link to the Creative Commons licence, and indicate if changes were made. The images or other third party material in this article are included in the article's Creative Commons licence, unless indicated otherwise in a credit line to the material. If material is not included in the article's Creative Commons licence and your intended use is not permitted by statutory regulation or exceeds the permitted use, you will need to obtain permission directly from the copyright holder. To view a copy of this licence, visit http://creativecommons.org/licenses/by/4.0/.

\section{References}

Aberle N, Hillebrand H, Grey J, Wiltshire KH (2005) Selectivity and competitive interactions between two benthic invertebrate grazers (Asellus aquaticus and Potamopyrgus antipodarum): an experimental study using 13C- and 15N-labelled diatoms. Freshw Biol 50(2):369-379. https://doi.org/10.1111/j.1365-2427.2004.01325.x

Arakelova KS (2001) The evaluation of individual production and scope for growth in aquatic sow bugs (Asellus aquaticus). Aquat Ecol 35(1):31-42. https://doi.org/10.1023/A:1011446224456

Arce E, Archaimbault V, Mondy CP, Usseglio-Polatera P (2014) Recovery dynamics in invertebrate communities following water-quality improvement: taxonomy- vs trait-based assessment. Freshw Sci 33(4):1060-1073. https://doi.org/10.1086/678673

Basen T, Gergs R, Rothhaupt KO, Martin-Creuzburg D (2013) Phytoplankton food quality effects on gammarids: benthic-pelagic coupling mediated by an invasive freshwater clam. Can J Fish Aquat Sci 70(2):198-207. https://doi.org/10.1139/cjfas-2012-0188

Bundschuh M, McKie BG (2016) An ecological and ecotoxicological perspective on fine particulate organic matter in streams. Freshw Biol 61(12):2063-2074. https://doi.org/10.1111/fwb.12608

Burdon FJ, Munz NA, Reyes M, Focks A, Joss A, Räsänen K, Stamm C (2019) Agriculture versus wastewater pollution as drivers of macroinvertebrate community structure in streams. Sci Total Environ 659:1256-1265. https://doi.org/10.1016/j.scitotenv.2018.12.372

Chambers MR (1977) A comparison of the population ecology of Asellus aquaticus (L.) and Asellus meridianus rac in the reed beds of the Tjeukemeer. Hydrobiologia 53(2):147-154. https://doi.org/10. 1007/BF00029293

Chauvet E, Giani N, Gessner MO (1993) Breakdown and invertebrate colonization of leaf litter in two contrasting streams: significance of oligochaetes in a large River. Can J Fish Aquat Sci 50:488-495

Cook AR, Hoellein TJ (2016) Environmental drivers of leaf breakdown in an urban watershed. Freshw Sci 35(1):311-323. https://doi.org/ $10.1086 / 685086$

Costantini ML, Rossi L (1998) Competition between two aquatic detritivorous isopods - a laboratory study. Hydrobiologia 368(1):1727. https://doi.org/10.1023/A:1003296620693

Creed RP, Cherry RP, Pflaum JR, Wood CJ (2009) Dominant species can produce a negative relationship between species diversity and ecosystem function. Oikos 118(5):723-732. https://doi.org/ 10.1111/j.1600-0706.2008.17212.x

Dinno A (2017) dunn.test: Dunn's test of multiple comparisons using rank sums. R package version 1.3.5. https://CRAN.R-project.org/ package $=$ dunn.test

dos Reis Oliveira PC, Kraak MHS, Pena-Ortiz M, van der Geest HG, Verdonschot PFM (2020) Responses of macroinvertebrate communities to land use specific sediment food and habitat characteristics in lowland streams. Sci Total Environ 703:135060. https:// doi.org/10.1016/j.scitotenv.2019.135060

Drewes CD, Fourtner CR (1989) Hindsight and rapid escape in a freshwater oligochaete. Biol Bull 177(3):363-371. https://doi.org/10. 2307/1541596

Englert D, Zubrod JP, Schulz R, Bundschuh M (2013) Effects of municipal wastewater on aquatic ecosystem structure and function in the receiving stream. Sci Total Environ 454-455:401-410. https://doi.org/10.1016/j.scitotenv.2013.03.025

Finogenova NP, Lovasheva TM (1987) Growth of Tubifex tubifex MULLER (Oligochaeta, Tubificidae) under various trophic conditions. Int Revue Ges Hydrobiol Hydrogr 72(6):709-726

Fugère $\mathrm{V}$, Andino $\mathrm{P}$, Espinosa $\mathrm{R}$, Anthelme $\mathrm{F}$, Jacobsen $\mathrm{D}$, Dangles $\mathrm{O}$ (2012) Testing the stress-gradient hypothesis with aquatic detritivorous invertebrates: insights for biodiversity-ecosystem functioning research. J Anim Ecol 81(6):1259-1267. https://doi.org/ 10.1111/j.1365-2656.2012.01994.x

Gautreau E, Volatier L, Nogaro G, Gouze E, Mermillod-Blondin F (2020) The influence of bioturbation and water column oxygenation on nutrient recycling in reservoir sediments. Hydrobiologia 847(4):1027-1040. https://doi.org/10.1007/s10750-019-04166-0

Gieswein A, Hering D, Lorenz AW (2019) Development and validation of a macroinvertebrate-based biomonitoring tool to assess fine sediment impact in small mountain streams. Sci Total Environ 652:1290-1301. https://doi.org/10.1016/j.scitotenv.2018.10.180

González SO, Almeida CA, Calderón M, Mallea MA, González P (2014) Assessment of the water self-purification capacity on a river affected by organic pollution: application of chemometrics in spatial and temporal variations. Environ Sci Pollut Res 21(18):10583-10593. https://doi.org/10.1007/s11356-014-3098-y

Graça MAS (2001) The role of invertebrates on leaf litter decomposition in streams-a review. Int Rev Hydrobiol 86(4-5):383-393. https://doi.org/10.1002/1522-2632(200107)86:4/5\%3c383::AIDIROH383\%3e3.0.CO;2-D

Graça MAS, Matlby L, Calow P (1993) Importance of fungi in the diet of Gammarus pulex and Asellus aquaticus. Oecologia 96:304-309

Gresens SE (1995) Grazer diversity, competition and the response of the periphyton community. Oikos 73(3):336-346

Halpern BS, Silliman BR, Olden JD, Bruno JP, Bertness MD (2007) Incorporating positive interactions in aquatic restoration and conservation. Front Ecol Environ 5(3):153-160. https://doi.org/10. 1890/1540-9295(2007)5[153:IPIIAR]2.0.CO;2

Hamdhani H, Eppehimer DE, Bogan MT (2020) Release of treated effluent into streams: a global review of ecological impacts with a consideration of its potential use for environmental flows. Freshw Biol 65(9):1657-1670. https://doi.org/10.1111/fwb.13519

Hay ME, Parker JD, Burkepile DE, Caudill CC, Wilson AE, Hallinan ZP, Chequer AD (2004) Mutualisms and aquatic community structure: the enemy of my enemy is my friend. Annu Rev Ecol Evol Syst 35:175-197. https://doi.org/10.1146/annurev.ecolsys. 34.011802 .132357

Heard SB (1994) Processing chain ecology: resource condition and interspecific interactions. J Anim Ecol 63(2):451-464

Hieber M, Gessner MO (2002) Contribution of stream detrivores, fungi, and bacteria to leaf breakdown based on biomass estimates. Ecology 83(4):1026-1038. https://doi.org/10.1890/00129658(2002)083[1026:COSDFA]2.0.CO;2 
Holomuzki JR, Feminella JW, Power ME (2010) Biotic interactions in freshwater benthic habitats. J N Am Benthol Soc 29(1):220-244. https://doi.org/10.1899/08-044.1

Hunting ER, Whatley MH, van der Geest HG, Mulder C, Kraak MHS, Breure AM, Admiraal W (2012) Invertebrate footprints on detritus processing, bacterial community structure, and spatiotemporal redox profiles. Freshw Sci 31(3):724-732. https://doi.org/10.1899/ $11-134.1$

Jonsson M, Malmqvist B (2000) Ecosystem process rate increases with animal species richness: evidence from leaf-eating, aquatic insects. Oikos 89(3):519-523. https://doi.org/10.1034/j.16000706.2000.890311.x

Jonsson M, Malmqvist B (2005) Species richness and composition effects in a detrital processing chain. J N Am Benthol Soc 24(4):798-806

Kassambara (2020). ggpubr: 'ggplot2' Based publication ready plots. $\mathrm{R}$ package version 0.4.0. https://CRAN.R-project.org/package $=$ ggpubr

Little CJ, Altermatt F (2018) Species turnover and invasion of dominant freshwater invertebrates alter biodiversity-ecosystem-function relationship. Ecol Monogr 88(3):461-480. https://doi.org/10. 1002/ecm.1299

Marcus JH, Sutcliffe DWW, Willoughby LG (1978) Feeding and growth of Asellus aquaticus (Isopoda) on food items from the littoral of Windermere, including green leaves of Elodea canadensis. Freshw Biol 8(6):505-519. https://doi.org/10.1111/j.1365-2427. 1978.tb01473.x

McKie BG, Woodward G, Hladyz S, Nistorescu M, Preda E, Popescu C, Malmqvist B (2008) Ecosystem functioning in stream assemblages from different regions: contrasting responses to variation in detritivore richness, evenness and density. J Anim Ecol 77(3):495-504. https://doi.org/10.1111/j.1365-2656.2008.01357.x

McKie BG, Schindler M, Gessner MO, Malmqvist B (2009) Placing biodiversity and ecosystem functioning in context: environmental perturbations and the effects of species richness in a stream field experiment. Oecologia 160(4):757-770. https://doi.org/10.1007/ s00442-009-1336-7

Mermillod-Blondin F, CreuzedesChatelliers M, Gerino M, Gaudet JP (2000) Testing the effect of Limnodrilus sp (Oligochaeta, Tubificidae) on organic matter and nutrient processing in the hyporheic zone: a microcosm method. Archiv Fur Hydrobiol 149(3):467487. https://doi.org/10.1127/archiv-hydrobiol/149/2000/467

Mermillod-Blondin F, Gerino M, desChatelliers MC, Degrange V (2002) Functional diversity among 3 detritivorous hyporheic invertebrates: an experimental study in microcosms. J N Am Benthol Soc 21(1):132-149. https://doi.org/10.2307/1468305

Mermillod-Blondin F, Gérino M, Sauvage S, Châtelliers MCD (2004) Influence of nontrophic interactions between benthic invertebrates on river sediment processes: a microcosm study. Can J Fish Aquat Sci 61(10):1817-1831. https://doi.org/10.1139/F04-114

Milbrink G (1993) Evidence for mutualistic interactions in freshwater oligocheate communities. Oikos 68(2):317-322

Mor JR, Dolédec S, Acuña V, Sabater S, Muñoz I (2019) Invertebrate community responses to urban wastewater effluent pollution under different hydro-morphological conditions. Environ Pollut 252:483-492. https://doi.org/10.1016/j.envpol.2019.05.114

Murphy PM, Learner MA (1982) The life history and production of Asellus aquaticus (Crustacea: Isopoda) in the River Ely. South Wales Freshw Biol 12(5):435-444. https://doi.org/10.1111/j.13652427.1982.tb00638.x
Newrkla P, Mutayoba S (1987) Why and where do oligochaetes hide their cocoons? Hydrobiologia 155(1):171-178. https://doi.org/10. 1007/BF00025646

Ohta T, Matsunaga S, Niwa S, Kawamura K, Hiura T (2016) Detritivore stoichiometric diversity alters litter processing efficiency in a freshwater ecosystem. Oikos 125(8):1162-1172. https://doi.org/ 10.1111/oik.02788

Ratsak CH, Verkuijlen J (2006) Sludge reduction by predatory activity of aquatic oligochaetes in wastewater treatment plants: science or fiction? A review. Hydrobiologia 564(1):197-211. https://doi.org/ 10.1007/s10750-005-1719-7

R Core Team (2020) R: a language and environment for statistical computing. R Foundation for Statistical Computing, Vienna, Austria. https://www.R-project.org/

Rueda J, Camacho A, Mezquita F, Hernández R, Roca JR (2002) Effect of episodic and regular sewage discharges on the water chemistry and macroinvertebrate fauna of a Mediterranean stream. Water Air Soil Pollut 140(1-4):425-444. https://doi.org/10.1023/A:10201 90227581

Ruggiero A, Solimini AG, Carchini G (2006) Effects of a waste water treatment plant on organic matter dynamics and ecosystem functioning in a Mediterranean stream. Ann Limnol 42(2):97-107. https://doi.org/10.1051/limn/2006014

Sánchez-Morales M, Sabater F, Muñoz I (2018) Effects of urban wastewater on hyporheic habitat and invertebrates in Mediterranean streams. Sci Total Environ 642:937-945. https://doi.org/10.1016/j. scitotenv.2018.06.132

Schuijt LM, van Bergen TJHM, Lamers LPM, Smolders AJP, Verdonschot PFM (2021) Aquatic worms (Tubificidae) facilitate productivity of macrophyte Azolla filiculoides in a wastewater biocascade system. Sci Total Environ 787:147538. https://doi.org/ 10.1016/j.scitotenv.2021.147538

Silknetter S, Creed RP, Brown BL, Frimpong EA, Skelton J, Peoples BK (2020) Positive biotic interactions in freshwaters: a review and research directive. Freshw Biol 65(4):811-832. https://doi. org/10.1111/fwb.13476

Tonin AM, Pozo J, Monroy S, Basaguren A, Pérez J, Gonçalves JF, Boyero L (2018) Interactions between large and small detritivores influence how biodiversity impacts litter decomposition. J Anim Ecol 87(5):1465-1474. https://doi.org/10.1111/1365-2656.12876

Westveer JJ, Verdonschot PFM, Verdonschot RCM (2018) Biotic interactions enhance survival and fitness in the caddisfly Micropterna sequax (Trichoptera: Limnephilidae). Hydrobiologia 818(1):3141. https://doi.org/10.1007/s10750-017-3493-8

Wickham (2016) ggplot2: elegant graphics for Data analysis. Springer, New York

Wisniewski RJ (1979) Investigations into the reproduction and mortality of Tubificidae in lakes. Ekologia Polska 27(3):463-479

Zoran MJ, Drewes CD (1987) Rapid escape reflexes in aquatic oligochaetes: variations in design and function of evolutionarily conserved giant fiber systems. J Comp Physiol A 161(5):729-738. https://doi.org/10.1007/BF00605014

Publisher's Note Springer Nature remains neutral with regard to jurisdictional claims in published maps and institutional affiliations. 